\title{
Protein, Organized by Origin
}

National Cancer Institute

\section{Source}

National Cancer Institute. Protein, Organized by Origin. NCI Thesaurus. Code C20032.

Org anizing term for the Proteins tree 